\title{
PENGEMBANGAN APLIKASI QnA UNTUK PENDAFTARAN MAHASISWA BARU STMIK AKAKOM
}

\author{
M. Agung Nugroho ${ }^{1)}$, Ariesta Damayanti ${ }^{2)}$, Muhammad Fahrur Rifai ${ }^{3)}$, Syamsu Windarti ${ }^{4)}$ \\ 1), 2),3) Informatika, STMIK AKAKOM Yogyakarta \\ 4) Manajemen Informasi Kesehatan, STIKES akbidyo \\ email: $\underline{\text { m.agung.n@akakom.ac.id }}{ }^{1)}, \underline{\text { iest_ayanthi@akakom.ac.id }}{ }^{2)}, \underline{\text { mfahrurrifai@gmail.com }}^{3)}$, \\ windartisyamsu@gmail.com ${ }^{4}$
}

\begin{abstract}
Abstraksi
Setiap tahunnya kampus STMIK AKAKOM membuka pendaftaran mahasiswa baru melalui media offline dan online. Melalui media online digunakan beberapa media seperti website, social media, dan email. Namun pada media seperti social media terdapat pertanyaan-pertanyaan yang sering muncul terkait informasi pendaftaran mahasiswa baru. Dengan keterbatasan SDM untuk selalu online selama 24 jam, sehingga diperlukan suatu model alternatif untuk tetap memberikan jawaban atas pertanyaan-pertanyaan tersebut, meskipun pengelola social media sedang tidak online. Dalam perkembangan teknologi saat ini, dimungkinkan untuk membuat model knowledge base yang berupa rangkuman pertanyaan dan jawaban atas topik tertentu. Knowledge base ini kemudian dapat dijadikan model untuk membuat skema prototype aplikasi yang dapat memberikan jawaban, jika terdapat pertanyaan terkait pendaftaran mahasiswa baru. Penelitian ini bertujuan memberikan kemudahan dalam proses tanya jawab dengan menggunakan aplikasi berbasis google dialogflow khusus untuk pendaftaran mahasiswa baru.
\end{abstract}

\section{Kata Kunci :}

NLP, Knowledge Management, Chatbot, Dialogflow

\begin{abstract}
STMIK AKAKOM annually opens new student registration through offline and online media. Through online media, several media such as websites, social media and email are used. However, on media such as social media, there are questions that often arise regarding new student registration information. With limited human resources to always be online for 24 hours, an alternative model is needed to provide answers to these questions, even though the social media manager offline. Nowadays. In the term of technological developments, it is possible to create a model of knowledge base in the form of a summary of questions and answers to certain topics. This knowledge base can use as a model for creating a prototype application that can provide answers if there are questions related to new student registration. This study aims to provide convenience in the question and answer process by using a Google Dialogflow.
\end{abstract}

Keywords :

NLP, Knowledge Management, Chatbot, Dialogflow

\section{Pendahuluan}

STMIK AKAKOM setiap tahunnya membuka pendaftaran mahasiswa baru melalui media offline dan online. Melalui media online digunakan beberapa media seperti website, social media, dan email. Namun pada media seperti social media terdapat pertanyaan-pertanyaan yang sering muncul terkait informasi pendaftaran mahasiswa baru. Dengan keterbatasan SDM untuk selalu online selama 24 jam, sehingga diperlukan suatu model alternatif untuk tetap memberikan jawaban atas pertanyaan-pertanyaan tersebut, meskipun pengelola social media sedang tidak online.

Dalam perkembangan teknologi saat ini, dimungkinkan untuk membuat model knowledge base yang berupa rangkuman pertanyaan dan jawaban atas topik tertentu. Knowledge base ini kemudian dapat dijadikan model untuk membuat skema prototype aplikasi yang dapat memberikan jawaban, jika terdapat pertanyaan terkait pendaftaran mahasiswa baru.

Pada penilitian ini akan mengembangkan teknologi chatbot dengan fungsi untuk menangani keterbatasan pada Customer Services. Chatbot adalah aplikasi yang memiliki kecerdasan buatan yang memiliki desain untuk dapat berkomunikasi langsung dengan manusia melalui media tertentu misalkan chat [1]. Dengan penelitian ini diharapkan mampu memberikan solusi dalam menangani masalah pada tim pendaftaran mahasiswa baru saat ini.

\section{Tinjauan Pustaka \\ A. Telegram}


Telegram merupakan system pengiriman pesan yang berjalan dalam berbagai platform system operasi dan memiliki kelebihan dari sisi pengamanan data pengguna. Telegram memiliki mekanisme yang dapat digabungkan dengan fungsionalitas dari program bot, sehingga aplikasi ini dapat menjawab pertanyaan dan memberikan informasi secara otomatis layaknya percakapan pada chatting [2].

\section{B. Natural Language Processing}

Natural Language Processing (NLP) merupakan salah satu cabang ilmu AI yang berfokus pada pengolahan bahasa natural. Bahasa natural adalah bahasa yang secara umum digunakan oleh manusia dalam berkomunikasi satu sama lain. Penelitian menggunakan pendekatan leksikon dan NLP sebelumnya telah digunakan untuk penyaringan gejala depresi pada pengguna Twitter, hasilnya diperoleh bahwa pendekatan leksikon dan NLP memiliki akurasi lebih baik dari pada menggunakan pendekatan machine learning [3].

\section{Chatbot}

Chatbot (bot) merupakan salah satu teknologi artificial inteligence berbasis audio dan teks yang mampu mensimulasikan cara berperilaku dan berbicara layaknya manusia sebagai mitra percakapan. Respon yang diberikan oleh chatbot tergantung dari kata kunci input yang dimulai. Chatbot akan membalas kata kunci dengan pola yang paling mirip dari basis data tekstual [4]. Chatbot merupakan implementasi dari bidang ilmu natural language processing (NLP), machine learning, rekayasa perangkat lunak dan artificial intellegence. Sebuah chatbot dapat menggunakan artificial intelligence atau kecerdasan buatan, ketika sebuah input bahasa alami yang terdiri dari beberapa kata dengan susunan yang tidak sama diimplementasikan pada kalimat, namun system ini dapat juga mempelajari masukan yang memiliki arti sama dengan masukan sebelumnya, yang pada akhirnya system ini mampu merespon dengan balasan sesuai seperti halnya komunikasi yang terjadi antar sesama manusia dengan menggunakan aplikasi chat [5].

\section{Dialogflow}

Dialogflow adalah platform NLP yang membuatnya mudah untuk merancang dan mengintegrasikan antarmuka pengguna percakapan ke dalam aplikasi seluler, aplikasi web, perangkat, bot, sistem respons suara interaktif dan sebagainya. Dengan menggunakan Dialogflow, dapat memberikan cara baru dan menarik bagi pengguna untuk berinteraksi dengan produk tertentu. Dialogflow dapat menganalisis berbagai jenis masukan dari pelanggan, termasuk masukan teks atau audio (seperti dari telepon atau rekaman suara). Itu juga dapat menanggapi pelanggan dengan beberapa cara, baik melalui teks atau dengan ucapan sintetis [6].
Intent merupakan tindakan khusus yang dapat dilakukan pengguna dengan menggunakan salah satu istilah yang ditentukan di konsol Dialogflow. Misalnya, pengguna dapat bertanya "Apakah akan turun hujan hari ini?" Atau "Di mana restoran pizza terdekat" - jika ini adalah istilah yang didefinisikan dalam konsol, maka mereka akan terdeteksi oleh Dialogflow dan maksud yang ditentukan di bawah kehendak dipicu. Sementara Entitas adalah mekanisme Dialogflow untuk mengidentifikasi dan mengekstraksi data yang berguna dari input bahasa alami. Meskipun maksud memungkinkan agen untuk memahami motivasi di balik input pengguna tertentu, entitas digunakan untuk memilih informasi tertentu yang disebutkan pengguna - apa pun dari alamat jalan sampai nama produk atau jumlah dengan unit. Setiap data penting yang ingin didapatkan dari permintaan pengguna akan memiliki entitas yang sesuai [5].

\section{E. Penelitian chatbot}

Penelitian ini merupakan pengembangan dari beberapa penelitian sebelumnya, yaitu:

Aplikasi customer service dapat di rancang menggunakan mekanisme fitur chatbot yang dapat memudahkan system dalam membalas pertanyaan dari pelanggan. Namun system ini memiliki kekurangan karena hanya terbatas untuk organisasi atau institusi tertentu dengan menggunakan platform web. Penelitian ini dikembangkan dengan metode Extreme Programming dan terintegrasi dengan web CMS perusahaan [1].

Pada kasus tertentu misalkan pada institusi sekolah seperti SMA IT ALIA Tangerang, siswa menghadapi persoalan untuk mendapatkan materi-materi yang dapat diakses ketika di luar jam sekolah atau jika tidak dapat menghadiri jam mata pelajaran tertentu karena ijin. Untuk mengatasi persoalan ini, dikembangkan sebuah system dengan memanfaatkan API dialogflow dengan mengambil database dari system elearning berbasis moodle yang di miliki sekolah. Sistem ini dapat diakses oleh siswa dengan menggunakan perangkat mobile dan berbasis chat. Aplikasi ini dapat memudahkan siswa dalam mengakses materi pelajaran dengan berkomunikasi langsung dalam system chat yang telah tersedia. [7].

Pengembangan system chatbot juga dapat digunakan dalam menangani order manajemen sistem pada UMKM. Dengan menggunakan system pengembangan aplikasi metode waterfall, chatbot ini berjalan menggunakan platform facebook messenger. Chatbot ini dapat mengelola pemesanan pelanggan, namun terdapat masalah pada system keamanan traksasi dari system tersebut [8].

Sistem chatbot tidak hanya dapat di integrasikan pada web CMS, elearning system, dan platform fa- 
cebook. Sistem ini dapat pula dikembangakan pada platform messanging lain seperti telegram. Telegram sudah memiliki fitur API yang ringan, dapat digunakan di berbagai system operasi, bersifat open source, serta mendapatkan support yang baik dari komunitas [9].

\section{Metode Penelitian}

\section{A. Prosedur dan Pengumpulan Data}

Metode pengumpulan data yang digunakan dalam penelitian ini adalah Wawancara. Wawancara merupakan percakapan antara dua orang atau lebih dan berlangsung antara narasumber dan pewawancara. Tujuan dari wawancara adalah untuk mendapatkan informasi yang tepat dari narasumber yang terpercaya. Dalam penelitian ini yang diwawancarai adalah pihak kampus STMIK AKAKOM Yogyakarta.

\section{B. Analisis Kebutuhan Sistem}

Analisis kebutuhan sistem adalah proses analisis setiap data yang dibutuhkan sebagai pendukung pengembangan aplikasi pada penelitian ini. Aplikasi yang dibuat mempunyai kebutuhan sistem sebagai berikut:

\section{Kebutuhan Fungsional Sistem}

Kebutuhan fungsional ini mendefinisikan aksi dasar yang harus diambil oleh perangkat lunak untuk menerima dan memproses masukan dan menghasilkan keluaran. Pada tabel kebutuhan fungsional sistem terdapat nomor fungsional dan deskripsi. Nomor digunakan untuk penomoran pada setiap fungsi yang ada. Deskripsi digunakan untuk keterangan fungsi apa yang terdapat pada sistem. Daftar kebutuhan fungsional sistem chatbot pada penelitian ini dapat dilihat pada Tabel 1.

Tabel 1 Tabel Kebutuhan Fungsional Sistem Untuk Chatbot

\begin{tabular}{|l|l|}
\hline No & Deskripsi \\
\hline 1 & Melakukan interaksi dengan bot \\
\hline
\end{tabular}

Tabel 1 merupakan daftar kebutuhan fungsional sistem chatbot pada aplikasi yang akan dikembangkan.

Tabel 2 Tabel Kebutuhan Fungsional Sistem Untuk Mengelola Data Informasi

\begin{tabular}{|l|l|}
\hline No & Deskripsi \\
\hline 1 & Login \\
\hline 2 & Mengelola informasi \\
\hline 3 & Mengelola intent \\
\hline 4 & Mengelola entity \\
\hline
\end{tabular}

Tabel 2 merupakan daftar kebutuhan fungsional sistem untuk mengelola data informasi pada aplikasi Sistem informasi akademik yang akan dikembangkan.

\section{Kebutuhan Non Fungsional Sistem}

Kebutuhan non fungsional adalah kebutuhan tambahan lainnya yang tidak langsung berhubungan dengan proses-proses yang ada. Pada Tabel 3 menampilkan daftar kebutuhan non fungsional sistem dari aplikasi yang akan dikembangkan.

Tabel 3 Tabel Kebutuhan Non Fungsional Sistem

\begin{tabular}{|l|l|}
\hline No & Deskripsi \\
\hline 1 & $\begin{array}{l}\text { Server admin harus terus dapat beroperasi 7 } \\
\text { hari per minggu, 24 jam per hari }\end{array}$ \\
\hline 2 & $\begin{array}{l}\text { Server admin harus mendukung bahasa } \\
\text { pemrograman PHP minimum versi 7.2 serta } \\
\text { mengaktifkan ekstensi mongodb }\end{array}$ \\
\hline 3 & $\begin{array}{l}\text { Sistem dapat digunakan kapan dan dimana } \\
\text { saja selagi terhubung dengan koneksi } \\
\text { internet }\end{array}$ \\
\hline 4 & $\begin{array}{l}\text { Chatbot hanya bisa dijalankan melalui web } \\
\text { browser }\end{array}$ \\
\hline
\end{tabular}

Tabel 3 menampilkan daftar non fungsional sistem pada penelitian ini. Aplikasi harus terus dapat beroperasi setiap saat, tampilan dari aplikasi juga harus mudah dipahami pengguna dan dapat digunakan dimana saja selama perangkat terkoneksi internet.

\section{Arsitektur}

Penelitian ini memanfaatkan fitur Bot dari Telegram yang digunakan untuk merespon pesan dari mahasiswa. Mahasiswa mengirimkan pertanyaan melalui aplikasi telegram yang sudah terpasang. Pesan diterima di Telegram Server dan diteruskan ke Dialogflow untuk Natural Language Processing-nya. Data yang sudah diprosess pada dialogflow kemudian diteruskan ke Bot Server menggunakan webhook. Bot Server akan memproses untuk mendapatkan data/jawaban dari Database dikirimkan kembali ke dialogflow dan kemudian dikirimkan ke client melalui telegram. Mahasiswa dapat merespon secara interaktif setiap respon pesan yang dikirimkan kembali oleh server untuk kasus tertentu. 


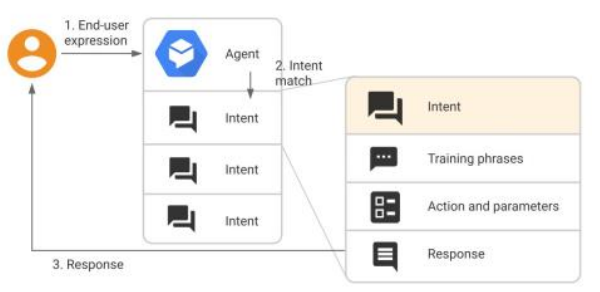

Gambar 1. Flow Sistem Dialogflow

Selain arsitektur sistem dari server admin. Gambar 1 adalah flow sederhana dari dialogflow ketika mencocokkan pertanyaan dari end-user ke dalam intentintent yang ada dalam dialogflow berdasarkan Training Phrases.

\section{Use Case Diagram}

Use Case Diagram Mahasiswa dapat dilihat pada Gambar 2.

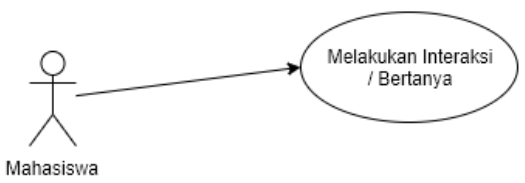

Gambar 2. Use Case Diagram Mahasiswa

Gambar 2 menampilkan urutan kegiatan yang dapat dilakukan oleh actor yaitu mahasiswa. Kegiatan yang dapat dilakukan mahasiswa melakukan interaksi dengan bertanya.

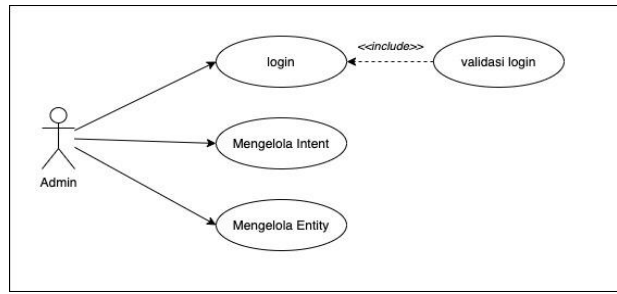

Gambar 3. Use Case Diagram Admin

Gambar 3 menampilkan kegiatan yang dapat dilakukan oleh actor yaitu admin. Kegiatan yang dapat dilakukan admin adalah melakukan login, mengelola intent dan mengelola entitas.

\section{Hasil dan Pembahasan}

\section{A. Pengujian}

Pengujian aplikasi dilakukan untuk menguji fungsifungsi dari aplikasi yang telah dibuat untuk mencari kesalahan/bug. Penelitian ini melakukan pengujian menggunakan teknik blackbox. Blackbox testing adalah pengujian yang didasarkan pada detail aplikasi seperti tampilan aplikasi, fungsi-fungsi yang ada pada aplikasi, dan kesesuaian alur fungsi dengan bisnis proses yang telah dirancang sebelumnya, pengujian ini juga telah diuji coba oleh beberapa penguji untuk melakukan pengujian fungsional dan User Interface / User Experience. Pengujian ini tidak melihat dan menguji kode program. Hasil pengujian dapat dilihat pada Tabel 4 dan Tabel 5.

\begin{tabular}{|c|c|c|c|c|}
\hline No & $\begin{array}{l}\text { Fungsi } \\
\text { yang diuji }\end{array}$ & Kondisi & $\begin{array}{l}\text { Output } \\
\text { yang } \\
\text { dihasilkan }\end{array}$ & $\begin{array}{l}\text { Status } \\
\text { pen- } \\
\text { gujian }\end{array}$ \\
\hline \multirow[t]{2}{*}{1} & $\begin{array}{l}\text { Masuk ap- } \\
\text { likasi }\end{array}$ & $\begin{array}{l}\text { Email dan } \\
\text { passowrd } \\
\text { benar }\end{array}$ & $\begin{array}{l}\text { Sukses ma- } \\
\text { suk aplikasi }\end{array}$ & valid \\
\hline & & $\begin{array}{l}\text { Email dan } \\
\text { password } \\
\text { salah mau- } \\
\text { pun kosong }\end{array}$ & $\begin{array}{l}\text { Gagal masuk } \\
\text { aplikasi dan } \\
\text { menampil- } \\
\text { kan pesan } \\
\text { kesalahan }\end{array}$ & valid \\
\hline 2 & $\begin{array}{l}\text { Melihat } \\
\text { data intent }\end{array}$ & $\begin{array}{l}\text { Pilih menu } \\
\text { intent }\end{array}$ & $\begin{array}{l}\text { Menampil- } \\
\text { kan data } \\
\text { intent }\end{array}$ & valid \\
\hline \multirow[t]{2}{*}{3} & $\begin{array}{l}\text { Menambah } \\
\text { intent }\end{array}$ & $\mid \begin{array}{lr}\text { Semua } & \text { ko- } \\
\text { lom } & \text { diisi } \\
\text { dengan } & \\
\text { benar } & \end{array}$ & $\begin{array}{l}\text { Sukses } \\
\text { membuat } \\
\text { intent }\end{array}$ & valid \\
\hline & & $\begin{array}{l}\text { Kolom tid- } \\
\text { ak diisi } \\
\text { dengan } \\
\text { benar mau- } \\
\text { pun salah }\end{array}$ & $\begin{array}{l}\text { Gagal mem- } \\
\text { buat intent } \\
\text { dan menam- } \\
\text { pilkan pesan } \\
\text { kesalahan }\end{array}$ & valid \\
\hline \multirow[t]{2}{*}{4} & $\begin{array}{l}\text { Mengubah } \\
\text { intent }\end{array}$ & $\begin{array}{|lr|}\text { Semua } & \text { ko- } \\
\text { lom diisi } \\
\text { dengan } \\
\text { benar }\end{array}$ & $\begin{array}{l}\text { Sukses men- } \\
\text { gubah intent }\end{array}$ & valid \\
\hline & & $\begin{array}{l}\text { Kolom tid- } \\
\text { ak diisi } \\
\text { dengan } \\
\text { benar mau- } \\
\text { pun salah }\end{array}$ & $\begin{array}{l}\text { Gagal men- } \\
\text { gubah intent } \\
\text { dan menam- } \\
\text { pilkan pesan } \\
\text { kesalahan } \\
\text { dan } \\
\text { mengem- } \\
\text { balikan data } \\
\text { yang dikirim }\end{array}$ & valid \\
\hline 5 & $\begin{array}{l}\text { Menghapus } \\
\text { data intent }\end{array}$ & $\begin{array}{l}\text { Tekan tom- } \\
\text { bol hapus } \\
\text { intent }\end{array}$ & $\begin{array}{l}\text { Data intent } \\
\text { berhasil } \\
\text { dihapus }\end{array}$ & valid \\
\hline 6 & $\begin{array}{l}\text { Melihat } \\
\text { data entitas }\end{array}$ & $\begin{array}{l}\text { Pilih menu } \\
\text { entitats }\end{array}$ & $\begin{array}{l}\text { Menampil- } \\
\text { kan data } \\
\text { entitas }\end{array}$ & valid \\
\hline \multirow[t]{2}{*}{7} & $\begin{array}{l}\text { Menambah } \\
\text { entitas }\end{array}$ & \begin{tabular}{|lr} 
Semua & ko- \\
lom & diisi \\
dengan & \\
benar &
\end{tabular} & $\begin{array}{l}\text { Sukses } \\
\text { menambah } \\
\text { entitas }\end{array}$ & valid \\
\hline & & Kolom tid- & Gagal & valid \\
\hline
\end{tabular}




\begin{tabular}{|c|c|c|c|c|}
\hline No & $\begin{array}{l}\text { Fungsi } \\
\text { yang diuji }\end{array}$ & Kondisi & $\begin{array}{l}\text { Output } \\
\text { yang } \\
\text { dihasilkan }\end{array}$ & $\begin{array}{l}\text { Status } \\
\text { pen- } \\
\text { gujian }\end{array}$ \\
\hline & & $\begin{array}{l}\text { ak diisi } \\
\text { dengan } \\
\text { benar mau- } \\
\text { pun salah }\end{array}$ & $\begin{array}{l}\text { menambah } \\
\text { entitas dan } \\
\text { menampil- } \\
\text { kan kesala- } \\
\text { han }\end{array}$ & \\
\hline \multirow[t]{2}{*}{8} & $\begin{array}{l}\text { Mengubah } \\
\text { entitas }\end{array}$ & $\begin{array}{l}\text { Semua ko- } \\
\text { lom diisi } \\
\text { dengan } \\
\text { benar }\end{array}$ & $\begin{array}{l}\text { Sukses men- } \\
\text { gubah entitas }\end{array}$ & valid \\
\hline & & $\begin{array}{l}\text { Kolom tid- } \\
\text { ak diisi } \\
\text { dengan } \\
\text { benar mau- } \\
\text { pun salah }\end{array}$ & $\begin{array}{l}\text { Gagal men- } \\
\text { gubah entitas } \\
\text { dan menam- } \\
\text { pilkan } \\
\text { kesalahan }\end{array}$ & valid \\
\hline 9 & $\begin{array}{l}\text { Menghapus } \\
\text { data entitas }\end{array}$ & $\begin{array}{l}\text { Tekan tom- } \\
\text { bol hapus } \\
\text { entitas }\end{array}$ & $\begin{array}{l}\text { Data entitas } \\
\text { berhasil } \\
\text { dihapus }\end{array}$ & valid \\
\hline
\end{tabular}

Tabel 5 Hasil pengujian bot

\begin{tabular}{|l|l|l|l|l|}
\hline No & $\begin{array}{l}\text { Fungsi yang } \\
\text { diuji }\end{array}$ & Kondisi & $\begin{array}{l}\text { Output } \\
\text { yang } \\
\text { dihasilk } \\
\text { an }\end{array}$ & $\begin{array}{l}\text { Status } \\
\text { pen- } \\
\text { gujian }\end{array}$ \\
\hline 1 & Bertanya & $\begin{array}{l}\text { Sesuai } \\
\text { dengan } \\
\text { training } \\
\text { pada } \\
\text { intent }\end{array}$ & $\begin{array}{l}\text { Mendap } \\
\text { atkan } \\
\text { jawaban } \\
\text { sesuai } \\
\text { intent }\end{array}$ & valid \\
\hline
\end{tabular}

Pada Tabel 4 dan 5 menunjukkan bahwa semua hasil pengujian bernilai valid. Berdasarkan hasil pengujian ini maka dapat disimpulkan bahwa aplikasi dapat berjalan baik dan sesuai dengan rancangan sebelumnya.

\section{B. Pembahasan}

Penggunaan library Dialogflow sangat mendukung dalam pembuatan bot khususnya pada bagian pengelolaan Intent dan Entitas pada halaman admin. Aplikasi atau dashboard admin dikembangkan dengan framework Laravel berbasis PHP, sementara untuk database, sistem ini dibangun diatas database NoSQL yaitu MongoDB.

Berdasarkan hasil uji coba yang telah dilakukan, sistem yang dirancang dalam bentuk chatbot dapat berjalan dengan baik sesuai dengan kriteria yang diujikan, seperti kondisi jaringan stabil, ini dikarenakan data yang diambil dan ditampilkan ke pengguna adalah data yang ditampilkan secara realtime, jadi setiap pengguna yang menggunakan aplikasi ini setiap mengakses di salah satu halaman akan secara otomatis atau tidak sadar akan melakukan request langsung ke server Dialogflow, sehingga website akan segera memberikan data informasi yang telah diolah saat itu juga dan akan ditampilkan pada aplikasi admin.

Penilaian pada uji coba diatas menggunakan Informasi valid atau tidak valid, pengujian pada Tabel 5 dilakukan atau ditujukan ke calon mahasiswa STMIK AKAKOM Yogyakarta dan untuk pengujian pada Tabel 4 dilakukan oleh pihak kampus, banyak masukan-masukan yang ditampung untuk kesempurnaan bot dan bertahap sedikit demi sedikit memperbaiki meminimalisir bug, ini bertujuan agar aplikasi yang dibangun benar-benar dapat digunakan secara baik dan benar.

Implementasi chatbot menggunakan halaman admin yang berisi informasi intent yang terintegrasi dengan dialogflow. Pada halaman ini ditampilkan daftar seluruh intent yang ada pada dialogflow. Data yang ditampilkan berupa ID Intent dari Dialogflow, Nama Intent, Training Phrases, Jawaban dari Dialogflow dan Jawaban dari Server Lokal. Informasi ini dapat dilihat pada gambar 4 .

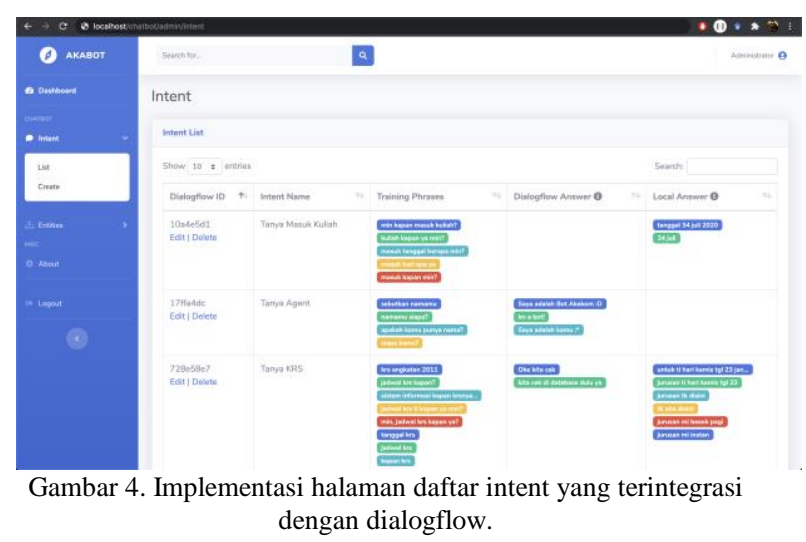

Hasil implementasi ini dapat membantu penambahan dan penghapusan intent untuk keperluan knowledge base. Sehingga pemilik layanan dapat menambahkan intent sendiri. Selain itu dalam system ini juga memungkinkan untuk mendata model pertanyaan dari calon mahasiswa baru, untuk kemudian direpresentasikan dalam bentuk jawaban yang tersedia.

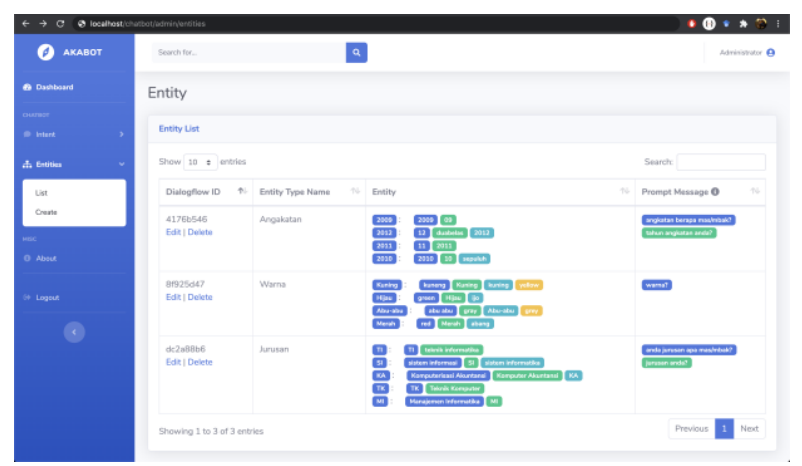

Gambar 5. Implementasi entitas pada sistem 
Pada gambar 5 ditampilkan daftar seluruh entitas yang ada pada dialogflow. Data yang ditampilkan berupa ID Entitas dari Dialogflow, Nama Tipe Entitas, Entitas dan Sinonim dan Pertanyaan yang diajukan kepada penanya ketika intent membutuhkan parameter. Dalam bagian ini, pemilik layanan dapat melakukan penambahan dan pengurangan entitas.

\section{Kesimpulan dan Saran}

Berdasarkan dari model perancangan sampai system ini dapat diimplementasikan, penelitian ini dapat menyimpulkan beberapa point, antara lain:

1. Untuk implementasi Natural Language Processing (NLP) dengan memanfaatkan API Dialogflow dapat berintegrasi dengan baik menggunakan platform telegram. Sistem dapat berfungsi dengan baik, sesuai dengan kriteria yang diujikan.

2. Sistem ini dapat berfungsi sesuai dengan kriteria yang diujikan dengan pemanfaatan framework Laravel dan database NoSQL MongoDB.

3. Sistem dapat digunakan oleh calon mahasiswa STMIK AKAKOM YOGYAKARTA dengan menggunakan aplikasi chat telegram atau dapat melakukan akses langsung ke form chat dengan menggunakan web browser.

4. Berdasarkan hasil ujicoba terhadap sistem ini, secara desain rancangan sampai proses implementasi dapat disimpulkan bahwa sistem sudah memiliki kesesuaian dengan rancangan desain sistem yang direncanakan dan dapat digunakan serta berfungsi dengan baik.

\section{Daftar Pustaka}

[1] A. R. Dwi, F. Imamah, Y. S. Mei Andre, F. Ilmu Komputer, U. Mercu Buana Jalan Menteng Raya No, and K. Sirih, "APLIKASI CHATBOT (MILKI BOT) YANG TERINTEGRASI DENGAN WEB CMS UNTUK CUSTOMER SERVICE PADA UKM MINSU," Nov. 2018. Accessed: Dec. 17, 2020. [Online]. Available: http://www.infodanpengertian.com/pengertian-.

[2] D. Utomo et al., "Membangun Sistem Mobile Monitoring Keamanan Web Aplikasi Menggunakan Suricata dan Bot Telegram Channel," journal.uhamka.ac.id, vol. 2, 2017, Accessed: Dec. 17, 2020. [Online]. Available: http://journal.uhamka.ac.id/index.php/teknoka/art icle/view/763.

[3] A. N. Rohman, E. Utami, and S. Raharjo, "Deteksi Emosi Media Sosial Menggunakan Pendekatan Leksikon dan Natural Language Processing," eksplora.stikom-bali.ac.id, doi: 10.30864/eksplora.v9i1.277.
[4] T. Rahman, "Implementasi Chatbot Menggunakan Dialogflow dan Messenger Untuk Layanan Customer Service Pada E-Commerce," 2019, Accessed: Dec. 17, 2020. [Online]. Available: http://eprints.bsi.ac.id/121/.

M. Rifai, "RANCANGAN DAN IMPLEMENTASI TELEGRAM CHATBOT UNTUK INFORMASI AKADEMIK DENGAN DIALOGFLOW," 2020. Accessed: Dec. 17, 2020. [Online]. Available: https://eprints.akakom.ac.id/8999/.

[6] O. Komawar, P. Thakar, R. Shetty, A. Bartakke, and P. M. Desai, "An Internet Relay Chat Bot using AIML," Int. J. Sci. Res., vol. 4, no. 10, pp. 2014-2016, 2015.

[7] E. Wijaya and P. Pebriantara, "Rancangan Bangun Aplikasi Pembelajaran dengan Memanfaatkan Chatbot API Dialogflow dan Moodle Berbasis Android Pada SMA IT ALIA Tangerang." Accessed: Dec. 17, 2020. [Online]. Available: https://search.unikom.ac.id/index.php/aisthebest/a rticle/view/1522.

[8] A. Iswandi, "IMPLEMENTASI CHATBOT PADA ORDER MANAGEMENT SYSTEM USAHA MIKRO KECIL MENENGAH," 2018. Accessed: Dec. 17, 2020. [Online]. Available: https://dspace.uii.ac.id/handle/123456789/5460.

[9] G. Sastrawangsa STMIK STIKOM Bali Jalan Raya Puputan no, "Konferensi Nasional Sistem \& Informatika," 2017. Accessed: Dec. 17, 2020. [Online]. Available: http://knsi.stikombali.ac.id/index.php/eproceedings/article/view/13 8 . 